\title{
Intensive WOM-behavior in the healthcare sector - the case of an Austrian hospital's Facebook site
}

\author{
Sebastian Martin ${ }^{1}$ (D) Birgit Grüb ${ }^{2}$
}

Received: 22 October 2019 / Accepted: 18 May 2020 / Published online: 3 June 2020

(C) The Author(s) 2020

\begin{abstract}
Patients frequently use Facebook for health-related reasons, like seeking of information or the recommendation of practitioners or hospitals. In this way, Facebook provides a powerful communication platform for electronic word-of-mouth (eWOM). Hospitals increasingly use Facebook to positively influence the perception of their brand reputation and performance. The present explorative study provides detailed information regarding eWOM behavior of persons on the Facebook page of an Upper Austrian hospital. Data of the hospital's Facebook page was gathered and analyzed with NodeXL. By using a text analysis, we categorized the hospitals' posts. Reactions towards the different types of postings were analyzed by counting emojis, the number of shares and comments. Within the study, there was an in-depth evaluation of communication data (313 posts of the hospital, more than 14,000 eWom actions by 3327 women, men and organizations). The study shows how heterogeneous users are in their eWOM behavior and that a variety of topics on the Facebook page stimulates electronic recommendations. One major finding of the study is that a significant part of the eWOM is done by only a few users. According to this, a so-called Intensive WOM Behavior (IWB) can be identified. Users of the IWB-group behave heterogeneously. Most react either with an emoji, a comment or a share. Only a few IWB-users respond with a combination of these eWOM-reactions. By providing first insights into the existence of IWB-users as well as their eWOM-behavior, this study offers new insights to eWOM in Facebook.
\end{abstract}

Keywords Word-of-mouth $\cdot$ eWOM $\cdot$ Recommendation $\cdot$ Healthcare $\cdot$ Hospital $\cdot$ Social media $\cdot$ Facebook

Sebastian Martin

Sebastian.Martin@fh-linz.at

1 University of Applied Sciences Upper Austria, Linz, Austria

2 Johannes Kepler University, Linz, Austria 


\section{Introduction}

Social media is increasingly used in the healthcare sector (Huppertz and Otto 2018; Smailhodzic et al. 2016), although its spread proceeds more slowly than in other industries (McCaughey et al. 2014). The current literature emphasizes social media as a cost-effective medium (Bonsón et al. 2015; Korda and Itani 2013), with a high diffusion among the population (Korda and Itani 2013), which may enhance the effectiveness of communication (Smailhodzic et al. 2016; Hawn 2009; Tursunbayeva et al. 2017) and therefore help improve the relationship between healthcare providers and patients (De Vries et al. 2012). As social media may directly affect health behavior (Korda and Itani 2013), health promotion and education (Korda and Itani 2013; Andersen et al. 2012; Abedin et al. 2017), it can additionally be used to foster patient welfare and safety (Andersen et al. 2012). Patients often use social media for healthrelated reasons (McCaughey et al. 2014; Korda and Itani 2013; Smailhodzic et al. 2016), such as "sharing of healthcare information e.g. health advise and tips, disease threat and prevention, treatment options, prescription and appointment with specialist" (Adzharuddin and Ramly 2015, p. 385). In this way, social media provides a powerful communication platform for word-of-mouth (WOM) (Chu and Kim 2011). Often, WOM advice is more trusted with regard to the quality of healthcare providers than official quality reports (Huppertz and Otto 2018). Therefore, healthcare providers need to be aware of the influence of WOM towards the attitudes as well as the behavior of their former, current and potential patients (Abrantes et al. 2013).

In contrast to traditional WOM, eWOM communication takes place via the Internet (Dellarocas 2003), including social networks (Ferguson 2008). The communicating persons do not have to be at the same place and additionally the information is spreading faster and often anonymous (Lis and Korchmar 2013). One specificity is that messages can be saved, persons can search specifically and recommendations can be retrieved by an unlimited number of persons (Hennig-Thurau et al. 2004). Hence, eWOM can have a more effective impact on consumers (and patients) in contrast to the traditional WOM (e.g. Smith et al. 2007; Edwards 2006). Hennig-Thurau et al. (2004) define this electronic form of WOM as "any positive or negative statement made by potential, actual, or former customers about a product or company, which is made available to a multitude of people and institutions via the Internet" (Hennig-Thurau et al. 2004, p. 39). The literature emphasizes the strong effect of (e) WOM towards the healthcare related behavior of individuals, including their decision-making (Gheorghe and Liao 2012; Duran et al. 2016; Khalid et al. 2013). "People are more conscious about their health and often when they go to the doctor or hospital they cannot check the quality $[\ldots]$ because they have not time or resources $[\ldots]$ so they take recommendation from their relative or friends" (Khalid et al. 2013, p. 51). Therefore, "peoples make their private health-care decisions based on word-of-mouth." (Khalid et al. 2013, p. 51). Such healthcare-related WOM might also be spread by Facebook.

Nevertheless, current studies do not focus such Facebook-WOM in the context of the healthcare sector (e.g. Gheorghe and Liao 2012; Khalid et al. 2013; Duran et al. 2016). To the best of our knowledge, there exists no in-depth eWOM-analysis of a hospital's Facebook site. Nonetheless, hospitals increasingly use social media (Griffis et al. 2014), especially Facebook (Griffis et al. 2014; Glover et al. 2015), to positively influence the perception of their brand reputation and performance (McCaughey et al. 
2014; Griffis et al. 2014). However, this relatively new form of communication requires careful application and does not always lead to the desired results (Korda and Itani 2013). In order to better understand the effects of the communication and the spread of information on social media (especially Facebook) and to be able to use Facebook more systematically for an organisation's purpose, it is important to gain deeper insights into eWOM-communication in social networks (Chu and Kim 2011; Kucukemiroglu and Kara 2015), including the Facebook sites of hospitals.

To address this research gap, this explorative study aims to investigate the intensity users engage in eWOM on the Facebook page of an Upper Austrian hospital. The current social media literature states existing differences between the users in Facebook. For example, women and men seem to differ in their Facebook-communication (e.g. Brandtzaeg 2017; Luarn et al. 2015; Oleszkiewicz et al. 2017). Also, the topics of interest may vary between different groups of Facebook users (Brandtzaeg 2017). Therefore, this study additionally includes a focus on the differences in the eWOM-behavior between Facebook users and towards the different types of information.

Hence, we address the following research questions:

RQ1: To what extent do users engage in eWOM at the hospital's Facebook page? RQ2: Are there any differences in the eWOM-behavior between Facebook users? RQ3: Are there any differences in the eWOM-behavior towards different types of information?

This study contributes to the current literature on Word-of-Mouth and Social Media by conducting the first in-depth eWOM analysis of a hospitals' Facebook site. We analyze 313 Facebook posts and the nearly 14,000 corresponding eWOM actions by 3327 women, men and organizations. This paper contributes to the literature of health communication and marketing by providing theoretical insights as well as empirical evidence about the characteristics of eWOM-behavior in social networks. Thereby, we focus specifically on differences between user groups and describe the group of intensive WOM users. The findings allow scholars as well as practitioners a more profound understanding of Facebook as a communication platform of electronic wordof-mouth in the healthcare sector.

\section{2 eWOM regarding a hospital's Facebook account}

Facebook-users may engage in three different forms of WOM-behavior: the seeking, giving or passing of opinions (Chu and Kim 2011). Regarding opinion seeking, patients often have a high demand for healthcare information. A frequent source of such information is the internet (McCaughey et al. 2014). Facebook in particular enables targeted searches for health information (Adzharuddin and Ramly 2015). Users can ask health-specific questions and other Facebook-users can directly respond to these questions. Especially, friends and peers are perceived as important sources of information that is often highly appreciated by patients (Kucukemiroglu and Kara 2015). Furthermore, patients may find and connect to other individuals with the same or a similar health condition (Greene et al. 2011; Korda and Itani 2013). The information collected via Facebook might help patients to assess the quality of a specific healthcare 
provider (Huppertz and Otto 2018) and thus may significantly influence the selection of the hospital (Glover et al. 2015). Concerning the giving or passing of opinions, Facebook enables patients to share their own hospital experiences (Huppertz and Otto 2018; Greene et al. 2011) with their various network contacts (Fu et al. 2017).

The essential types of eWOM on the Facebook site of a hospital include the emojireaction (like, love, wow, haha, sad, angry) to, comment on or the share of a posting (Liu et al. 2017; Kim and Yang 2017). Through emojis, users may signal positive, neutral or negative feelings (Gomes and Casais 2018). "Positive feelings are most prominent in emoji and reveal support, compassion and admiration [...]" (Gomes and Casais 2018, p. 591). 'Like' is the prevalent form of emoji-reaction. "This may be related with the universal use of the like button, in positive and negative occasions, or the fact that emoji buttons do not reveal just the feeling generated by threat appeals, but also might refer to the cause or organisation support." (Gomes and Casais 2018, p. 603). Therefore, pressing the Like-button of a specific post should not always be interpreted as an approval or feedback towards a specific posting content. Instead, single user might just simply express their sympathy with the organization in general.

"While a click is enough for [an emoji-reaction such as a] like, comment and share need additional actions that ask extra commitment or cognitive effort" (Kim and Yang 2017 , p. 442). This fact might partially explain why individuals more frequently 'like' Facebook postings, compared to posting shares or comments (Bonsón et al. 2015). "A single like can spread a message to over 130 friends (based on an average user's network of Facebook friends), not accounting for shared friends. Thus, a single 'like' has the ability to send over 130 personnel referrals (WOM)" (Swani et al. 2013, p. 285). The number of 'likes' is positively influenced by an increasing amount of fans on the hospital's Facebook site (Swani et al. 2013) as well as an emotional content of the released postings (Swani et al. 2013; Liu et al. 2017).

Regarding user characteristics, the current literature states various differences between the Facebook use of males and females. For example, some studies emphasize differences regarding the motives for the use of Facebook (Horzum 2016; Sheldon 2008), the topics of interest in Facebook (Brandtzaeg 2017), the expression of users in Facebook (Brandtzaeg 2017; Luarn et al. 2015; Oleszkiewicz et al. 2017), the emotional support in Facebook (Joiner et al. 2016) as well as the intensity of Facebook use (Przepiorka et al. 2016; Shepherd 2016). Therefore, it seems likely that gender aspects may also influence the eWOM-behavior of Facebook users. Consequently, this study includes a focus on potential gender-based differences.

The spread of eWOM through social networks is influenced by the strength of interpersonal relationships (Choi et al. 2017; Chu and Kim 2011; Granovetter 1973). Facebook users are connected to one another by either strong or weak ties (Capaldo 2007; Koroleva and Kane 2017; Johnson-Brown and Reingen 1987; Choi et al. 2017). Whereas strong ties characterize a close relationship with, for example, family members or friends, weak ties describe more distant and infrequent connections (Buchanan 2002; Hansen 1999). "[U]sers can often choose whether they want to share messages with both weak and strong ties or with strong ties only. For instance, popular platforms such as Facebook, LinkedIn, and Instagram allow users to share information with the general public or within friendship circles only.” (Choi et al. 2017, p. 5). For example, „consumers are more likely to share promotional messages with their strong rather than weak ties "(Choi et al. 2017, p. 1). 
The strength of ties significantly affects the network structure. Individuals who are connected by strong ties form single clusters (Granovetter 1973). Repeatedly, information is passed between close contacts and therefore circulates within the individual clusters. As a result, members of the cluster frequently receive redundant information (Hansen 1999; Dubini and Aldrich 1991; Paniculangara and Pacheco 2008). In contrast, weak ties bridge the clusters, allowing a transfer of new information from more distant parts of the network (Granovetter 1983; Jenssen and Koenig 2002; Chu and Kim 2011; Hansen 1999).

In addition to the stimulation of eWOM, for hospitals, it is becoming increasingly important to assess the quality of their services from the patient perspective. The described eWOM-communication in Facebook may help the healthcare provider to gain insights into the patient's experiences and feedback (Huppertz and Otto 2018; McCaughey et al. 2014). Facebook offers hospitals the opportunity to communicate with patients directly and record communication data in real time. In this way, Facebook can possibly be used to assess the quality of the hospital more quickly than traditional questionnaires (Griffis et al. 2014; Verhoef et al. 2014). However, the connection between the patient feedback in Facebook and the more traditional quality indicators of hospitals has not been a focus of the literature yet (Huppertz and Otto 2018; Glover et al. 2015). Moreover, it should be noted that Facebook communication does not necessarily only reflect the inpatient perspective. Outpatients, family members or other stakeholders may also share their thoughts and experiences on the hospital's Facebook page (Huppertz and Otto 2018). Nevertheless, by engaging in Facebook, hospitals have to consider ethical, legal, social, cultural and educational challenges, especially the handling of sensible health care data.

\section{Research design}

WOM is passed through the strong as well as weak ties (Goldenberg et al. 2007). "Whereas weak ties were found to play a crucial role in the flow of WOM information across groups, strong ties were shown to be important at the micro level of referral behavior. When both strong and weak ties were available as sources of information, strong ties were more likely than weak ties to be activated for the flow of information" (Johnson-Brown and Reingen 1987, p. 360). Since strong ties have a higher impact on the decision-making of individuals than weak ties (Johnson-Brown and Reingen 1987) and WOM strongly circulates inside the different network clusters, it seems to be important for the hospital to connect with users of various different clusters and stimulate these users to react (e.g., 'likes') to, comment on and share the organization's postings. In this way, WOM is passed to the directly connected network clusters (1st level) with a potentially high impact on its users. By using weak ties, individuals in the cluster might further diffuse the WOM to the indirectly connected clusters (2nd and 3rd levels). Figure 1 visualizes the integration of the case hospital's Facebook account in the network structure of its Facebook users.

The case hospital was found in 2017 through the merger of two hospitals affiliated with different religious orders. The hospital employs more than 3500 staff members, two sites and a capacity of nearly 1130 beds. Annually, the hospital provides treatments to 190,000 outpatients and 80,000 inpatients. The study includes 313 posts, which were published on the hospital's official Facebook account between January 1st 2017 and November 7th 2017. This timeframe seems to be especially interesting as the merged 


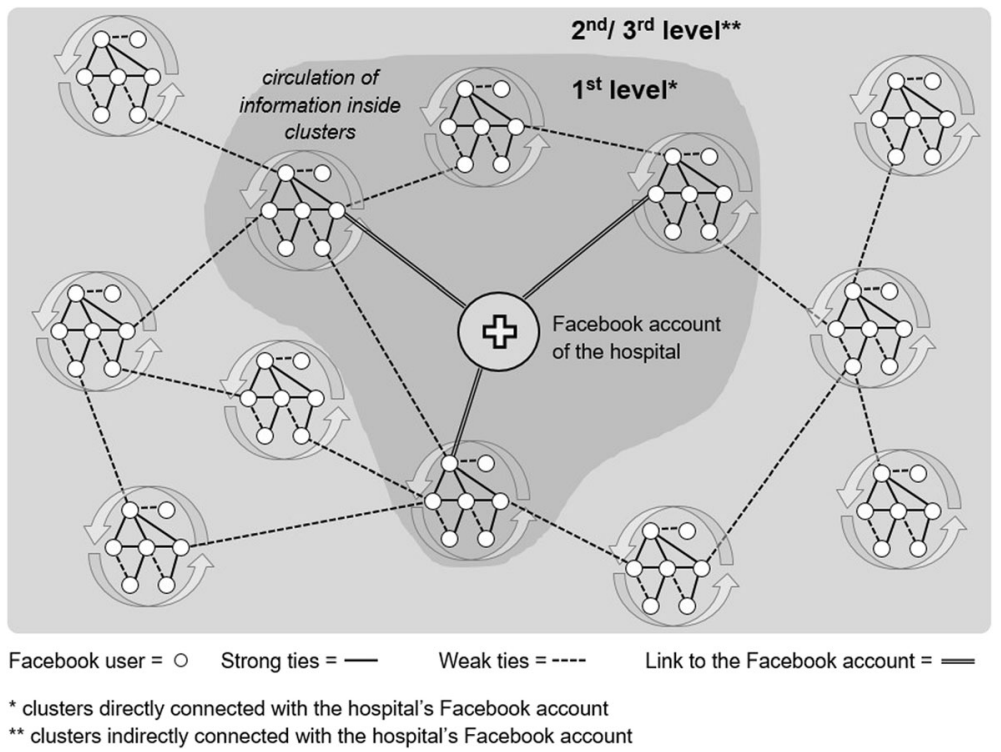

Fig. 1 The embeddedness of the hospital's Facebook account

hospital was found on January 1st 2017. Therefore, the period of examination additionally allows an investigation into what extent single aspects of the merger are actively communicated on the hospital's Facebook site as well as the resulting eWOM-behavior of the users.

To analyze the eWOM regarding the hospital's Facebook page, the released 313 postings as well as the corresponding emoji-reactions (like, love, wow, haha, sad, angry), comments and shares were collected systematically using the software NodeXL. The software tool was chosen as it allows a comprehensive data collection from Facebook sites as well as the visualization of complex network structures. "NodeXL uses a highly structured workbook template that includes multiple worksheets to store all the information needed to represent a network graph. Network relationships (i.e., graph edges) are represented as an 'edge list,' which contains all pairs of vertices that are connected in the network [...]. Other worksheets contain information about each vertex (i.e., node) and cluster (i.e., group). Visualization features allow users to display a range of network graph representations and map data attributes to visual properties including shape, color, size, transparency, and location." (Hansen et al. 2011, p. 54).

For the determined timeframe (January 1st 2017 to November 7th 2017), we used NodeXL to download the communication data directly from the hospitals' Facebook account. In total, we count 14,208 communication data sets, including the user ID (the name of the Facebook-user was anonymized), gender, the user's eWOM statement (emoji-reaction, comment or share) as well as the text of the hospital posting that was targeted by the eWOM statement. The user ID allows us to allocate the eWOM communication on the hospital's Facebook site to 2695 female and 589 male users as well as 43 organizations. Therefore, beside the analysis of the total emoji-reactions, comments or shares towards a specific company posting, we are additionally able to examine the individual eWOM behavior of a single user during the timeframe of the study. 
To analyze how different types of information affect users' emoji-reactions, comments and shares, the single postings of the hospital were categorized. The information categories were derived from a study of Richter et al. (2014) and adapted to the case study at hand. By conducting a content analysis, each of the 313 hospital postings were allocated to one of the categories. This categorization of information is described in Fig. 2 in more detail.

The final NodeXL-dataset includes the user-ID, gender, the specific eWOMstatement (reaction, comment or share) and the concerned information type of the Facebook posting (Fig. 2). In chapter 4.2., the NodeXL is used to calculate HarelKoren Fast Multiscale algorithm graphs that visualize the eWOM-behavior towards different types of information (compare with Figs. 6, 7 and 8). To further investigate the eWOM-behavior, the NodeXL-data is transferred to a separate Excel-file. The descriptive excel-analyses focus the users' eWOM engagement at the hospital's Facebook page as well as the differences in the eWOM-behavior between Facebook users (chapter 4.1., including Figs. 3, 4 and 5). The analysis also provides the data of chapter 4.2. (including Tables 1, 2 and 3).

\section{Analysis of empirical findings}

\subsection{Differences in the eWOM-behavior among Facebook users}

The data reveals an eWOM engagement of 2695 women, 589 men and 43 organizations on the hospital's Facebook site. Due to the privacy settings, a minority of the eWOM emoji-reactions and comments as well as a major proportion of the shares can not be linked to specific users and/or their gender. Nevertheless, $76 \%$ of the 12,631

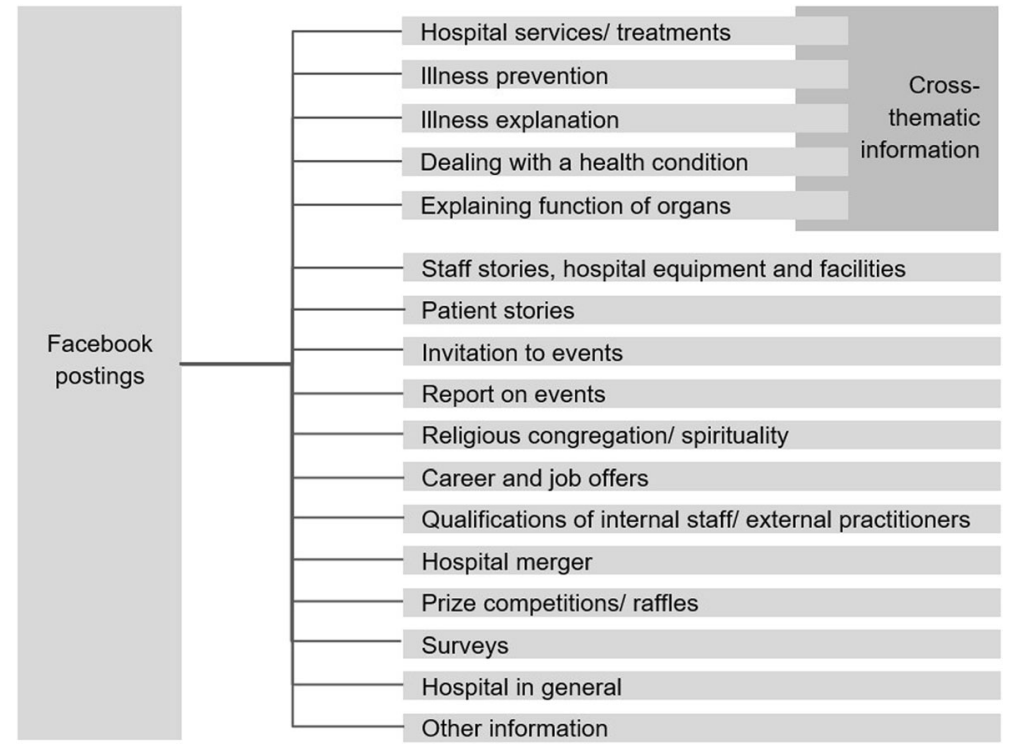

Fig. 2 Types of information in Facebook postings 


\section{2,695 women}

9,641 emoji-reactions (2,537 women)

- 194 comments (164 women)

215 shares ( 129 women)

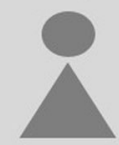

$76 \%$ of reactions $17 \%$ of shares

\section{9 men}

2,255 emoji-reactions (559 men)

51 comments ( 40 men)

55 shares ( 32 men)

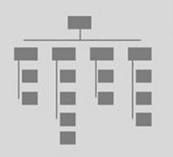

43 organizations

- 254 emoji-reactions (20 organizations)

17 comments (6 organizations)

43 shares (23 organizations)

$3 \%$ of shares

\section{Facebook-Posts}

- 12,631 emoji-reactions

- 12,241 like

- 223 love

- 12 haha

- 9 sad

- 273 comments

- 1,304 shares $^{*}$

\section{$18 \%$ of reactions}

$19 \%$ of comments $4 \%$ of shares
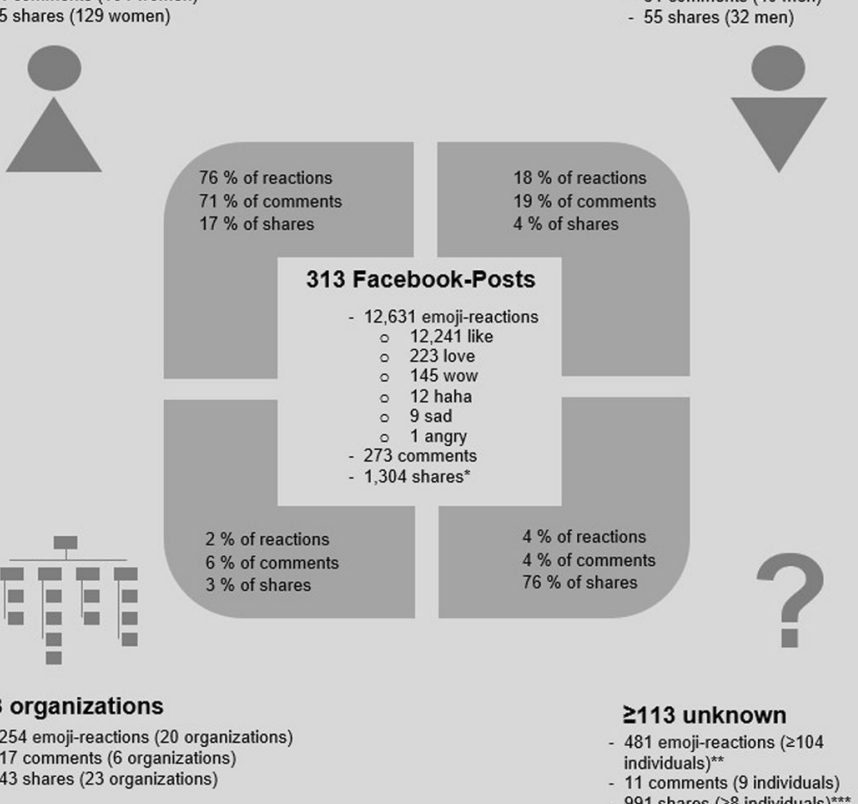

$2 \%$ of reactions

$6 \%$ of comments


$6 \%$ of shares

$\geq 113$ unknown

481 emoji-reactions ( 2104

individuals) $^{\star \star}$

- 11 comments (9 individuals)

- 991 shares ( $\geq 8$ individuals) ${ }^{* * \pi}$

* One posting of a job vacancy was shared 613 times

** 336 reactions of 104 different individuals, whose gender could not be identified. Due to the privacy settings, 145 reactions could not be linked to a specific user.

*** 18 shares of 8 different individuals, whose gender could not be identified. Due to the privacy settings, 973 shares could not be linked to a specific user.

Fig. 3 eWOM-behavior of women, men and organizations

emoji-reactions and $71 \%$ of the 273 comments are published by women. In addition, women share a Facebook post nearly four times more often than men and five times

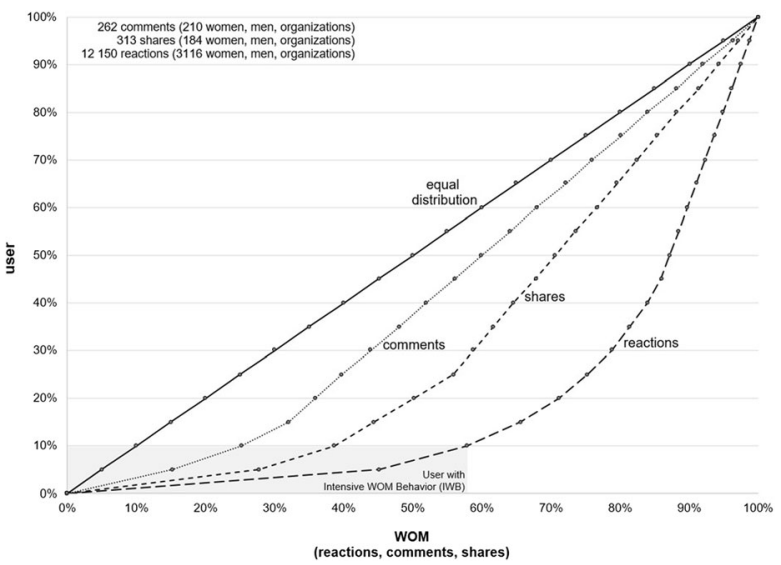

Fig. 4 Cumulative share of eWOM-behavior in the context of the cumulative share of users 


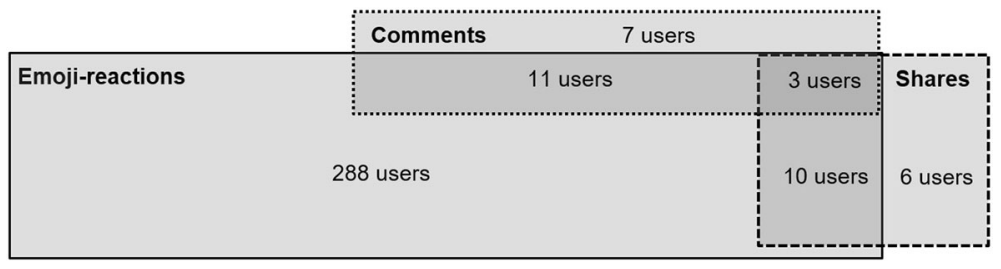

Fig. 5 Users with Intensive Wom-Behavior (IWB)

more often than organizations. Therefore, women seem to be the main source of eWOM regarding the case hospital's Facebook posts.

In addition to the source of the Facebook related eWOM, this study investigates the frequency of the individuals' emoji-reactions, comments and shares. Figure 4 graphs the cumulative share of eWOM-behavior in the context of the cumulative share of users. The hypothetical line at the $45^{\circ}$ angle illustrates an equal distribution of emojireactions, comments or shares among the women, men and organizations.

312 users reacted 7028 times, in other words, $10 \%$ of the users accounted for approximately $58 \%$ of the emoji-reactions. Eight of these users are responsible for 1355 emoji-reactions (each user between 120 and 243 reactions), 30 users for 1589 emoji-reactions (each user between 40 and 86 reactions) and 274 users for 4084 emojireactions (each user between 7 and 39 reactions). The 312 users comprise 251 woman, 56 men and 5 organizations. In addition to emoji-reactions, 66 comments were released by 21 users. Therefore, $10 \%$ of the users wrote $25 \%$ of the comments. Five of these users responded with 25 comments (each users between four and seven comments), while the remaining 16 users replied 41 comments (each user between two and three comments). The 66 comments are composed by 13 women, six men and two organizations. With respect to shares, 19 users shared postings 121 times, meaning that $10 \%$ of the users contributed 39\% of the shares. Seven users shared postings 77 times (each user between seven and 23 times), whereas 12 users accounted for 44 shares (each user between three and five times). The shares are spread by 11 women, four men and four organizations.

By separately analyzing the emoji-reactions, comments and shares, each time $10 \%$ of the users practiced an essential part of the eWOM. In this paper, we call this small proportion, users with "Intensive Wom-Behavior" (IWB). With other words, we define IWB-users as individuals with either more emoji-reactions, comments or shares than 90\% of the other users engaged in the eWOM-behavior at the hospital's Facebook site. Persons in the group of IWB-users demonstrate a strongly varying eWOM engagement. With more than $90 \%$ of these users, the broad majority either reacts, comments or shares a posting. Only around $7 \%$ of the IWB-users engage in a combination of such expressions. The allocation of the IWB-users towards the different types of eWOMcommunication is visualized in Fig. 5.

\section{2 eWOM-behavior towards different types of information}

The following subchapters describe the empirical findings on the eWOM-behavior (emoji-reactions, comments, shares) towards the different categories of information published on the hospital's Facebook page. 


\subsubsection{Emoji-reactions towards different types of information}

The hospital provides a variety of information on its Facebook site. $42 \%$ of the 313 postings concern the hospital services/treatments, the dealing with a specific health condition or invitations to events. Posts focusing on one of the three types of information receive 4185 emoji-reactions, which amount to $34 \%$ of the total reactions during the study timeframe. Nearly two-thirds of the postings on these topics

Table 1 Emoji-reactions towards different types of information

\begin{tabular}{|c|c|c|c|c|c|c|c|c|}
\hline \multirow{2}{*}{$\begin{array}{l}\text { Types of } \\
\text { information }\end{array}$} & \multirow{2}{*}{$\begin{array}{l}\text { Amount of } \\
\text { postings }(\mathrm{N})\end{array}$} & \multicolumn{3}{|c|}{ Emoji-reactions } & \multicolumn{4}{|l|}{ Users } \\
\hline & & $\begin{array}{l}\text { Total } \\
\text { amount of } \\
\text { reactions }\end{array}$ & $\begin{array}{l}\varnothing \\
\text { per } \\
\text { post }^{\mathrm{a}}\end{array}$ & $\begin{array}{l}\text { Amount } \\
\text { of } \\
\text { IWB } \\
\text { reactions }\end{array}$ & $\begin{array}{l}\% \text { of } \\
\text { women } \\
(N=2537)\end{array}$ & $\begin{array}{l}\% \text { of men } \\
(N=559)\end{array}$ & $\begin{array}{l}\% \text { of org. } \\
(N=20)\end{array}$ & $\begin{array}{l}\% \text { of } \\
\text { IWB- } \\
\text { user } \\
(N=312)\end{array}$ \\
\hline $\begin{array}{l}\text { Hospital services/ } \\
\text { treatments }\end{array}$ & 61 & 2764 & 45.3 & 1610 & $39 \%$ & $38 \%$ & $30 \%$ & $94 \%$ \\
\hline $\begin{array}{l}\text { Dealing with a } \\
\text { health } \\
\text { condition }\end{array}$ & 36 & 932 & 25.9 & 622 & $16 \%$ & $13 \%$ & $45 \%$ & $63 \%$ \\
\hline $\begin{array}{l}\text { Invitation to } \\
\text { events }\end{array}$ & 35 & 489 & 14.0 & 370 & $8 \%$ & $8 \%$ & $40 \%$ & $46 \%$ \\
\hline $\begin{array}{l}\text { Cross-thematic } \\
\text { information }\end{array}$ & 25 & 808 & 32.3 & 520 & $14 \%$ & $18 \%$ & $15 \%$ & $65 \%$ \\
\hline $\begin{array}{l}\text { Staff stories, } \\
\text { hospital } \\
\text { equipment and } \\
\text { facilities }\end{array}$ & 19 & 1492 & 78.5 & 745 & $30 \%$ & $31 \%$ & $15 \%$ & $83 \%$ \\
\hline Illness prevention & 19 & 433 & 22.8 & 293 & $8 \%$ & $10 \%$ & $40 \%$ & $46 \%$ \\
\hline $\begin{array}{l}\text { Illness } \\
\quad \text { explanation }\end{array}$ & 19 & 352 & 18.5 & 279 & $6 \%$ & $9 \%$ & $20 \%$ & $40 \%$ \\
\hline Patient stories & 18 & 1353 & 75.2 & 580 & $30 \%$ & $27 \%$ & $30 \%$ & $74 \%$ \\
\hline Report on events & 16 & 696 & 43.5 & 399 & $16 \%$ & $13 \%$ & $20 \%$ & $63 \%$ \\
\hline $\begin{array}{l}\text { Hospital in } \\
\text { general }\end{array}$ & 16 & 1059 & 66.2 & 568 & $21 \%$ & $21 \%$ & $25 \%$ & $73 \%$ \\
\hline Hospital merger & 10 & 430 & 43.0 & 240 & $10 \%$ & $12 \%$ & $20 \%$ & $44 \%$ \\
\hline $\begin{array}{l}\text { Religious } \\
\text { congregation/ } \\
\text { spirituality }\end{array}$ & 10 & 378 & 37.8 & 238 & $9 \%$ & $7 \%$ & $10 \%$ & $43 \%$ \\
\hline $\begin{array}{l}\text { Qualification of } \\
\text { internal } \\
\text { staff/ external } \\
\text { practitioners }\end{array}$ & 5 & 384 & 76.8 & 188 & $11 \%$ & $9 \%$ & $5 \%$ & $43 \%$ \\
\hline $\begin{array}{l}\text { Career and job } \\
\text { offers }\end{array}$ & 4 & 103 & 25.8 & 57 & $3 \%$ & $3 \%$ & $5 \%$ & $15 \%$ \\
\hline $\begin{array}{l}\text { Prize } \\
\text { competitions/ } \\
\text { raffles }\end{array}$ & 4 & 95 & 23.8 & 57 & $2 \%$ & $3 \%$ & $15 \%$ & $14 \%$ \\
\hline $\begin{array}{l}\text { Explaining } \\
\text { function } \\
\text { of organs }\end{array}$ & 3 & 59 & 19.7 & 40 & $1 \%$ & $2 \%$ & $5 \%$ & $10 \%$ \\
\hline Surveys & 2 & 34 & 17.0 & 26 & $1 \%$ & $1 \%$ & $5 \%$ & $7 \%$ \\
\hline Other information & 11 & 289 & 26.3 & 196 & $7 \%$ & $4 \%$ & $20 \%$ & $35 \%$ \\
\hline
\end{tabular}

a including reactions of women, men, organizations 
are published by the group of IWB-users. Still, these three most frequently posted topics do not have the highest emoji-reactions/ posting ratio. Instead, the average number of emoji-reactions per post is higher on postings regarding patient stories, staff stories/ hospital equipment/ facilities as well as qualification of internal staff/ external practitioners. To further analyze the potential effects of user characteristics towards the emoji-reactions on the different types of information, the users are subdivided into a group of women, a group of men and a group of organizations. The share in the women's group, which reacts with emoji to a specific type of information, is always similar to the share in the men's group. Therefore, even though more women react than men, the preference regarding the information content seems to be similar. In contrast to the women and men, a higher share of organizations react with emoji to types of information concerning illness prevention, invitations to events or the dealing with a specific health condition. Additionally, the groups of women, men and organizations are compared with a group of IWB-users. The share of users in the IWB-group that react with emoji to the single types of information is almost in all cases higher than the share in one of the other groups. In addition, a share higher than $40 \%$ of the IWB-users react to 13 of the 18 topics. This might be an indicator that IWB-users are more likely to react with emoji to a variety of information than their counterparts in the other groups. Table 1 presents the described findings in more detail.

A Harel-Koren Fast Multiscale algorithm graph is used in Fig. 6 to visualize the relationship between the 12,150 Facebook emoji-reactions of 3116 women, men or organizations and the different types of information provided. The single topics are shown as triangles and the 312 IWB-users are displayed enlarged. The broad majority of users only react with emoji towards one type of information. The algorithm arranges most of them at the edge of the figure. In contrast, nearly all IWB-users react with emoji to a broad variety of different topics, verifying our previous assumption. They are visualized between the single topics (triangles) in the center of the picture.

\subsubsection{Comments on different types of information}

The users commented on the 313 postings of the hospital 262 times. The three most frequently commented types of information are hospital services/ treatments, career/ job offers as well as patient stories. The highest comments/ posting ratio is achieved by postings concerning career/ job offers, prize competitions/ raffles and patient stories. IWB-users are responsible for $25 \%$ of the 262 comments. The shares of users that comment on the different content types strongly differs between the group of women, men, organisation and IWB-users. Furthermore, the share of users in the IWB-group that commented on single types of information is in more than half of the cases lower than the share in one of the other groups. In addition, a share higher than $20 \%$ of the IWB-users commented on five of the 18 topics. This might be an indicator that some IWB-users may still comment on several topics. Nevertheless, there might also be certain types of information which are commented on only by few IWB-users or not at all. Table 2 describes the findings in more detail.

Figure 7 visualizes the relationship between the 262 Facebook comments of 210 women, men or organizations and the different types of information provided. In accordance with Fig. 6, the single topics are shown as triangles and the 21 IWB- 
Table 2 Comments on different types of information

\begin{tabular}{|c|c|c|c|c|c|c|c|c|}
\hline \multirow{2}{*}{$\begin{array}{l}\text { Types of } \\
\text { information }\end{array}$} & \multirow{2}{*}{$\begin{array}{l}\text { Amount of } \\
\text { postings }(\mathrm{N})\end{array}$} & \multicolumn{3}{|l|}{ Comments } & \multicolumn{4}{|l|}{ Users } \\
\hline & & $\begin{array}{l}\text { Total } \\
\text { amount of } \\
\text { comments }^{\mathrm{a}}\end{array}$ & $\begin{array}{l}\varnothing \text { per } \\
\text { post }^{\mathrm{a}}\end{array}$ & $\begin{array}{l}\text { Amount } \\
\text { of IWB } \\
\text { comments }\end{array}$ & $\begin{array}{l}\% \text { of } \\
\text { women } \\
(N=164)\end{array}$ & $\begin{array}{l}\% \text { of } \\
\text { men } \\
(N=40)\end{array}$ & $\begin{array}{l}\% \text { of } \\
\text { org. } \\
(N=6)\end{array}$ & $\begin{array}{l}\% \text { of } \\
\text { IWB-user } \\
(N=21)\end{array}$ \\
\hline $\begin{array}{l}\text { Hospital } \\
\text { services/ } \\
\text { treatments }\end{array}$ & 61 & 50 & 0.8 & 15 & $19 \%$ & $33 \%$ & $17 \%$ & $52 \%$ \\
\hline $\begin{array}{l}\text { Dealing with a } \\
\text { health } \\
\text { condition }\end{array}$ & 36 & 14 & 0.4 & 5 & $6 \%$ & $8 \%$ & $17 \%$ & $24 \%$ \\
\hline $\begin{array}{l}\text { Invitation to } \\
\text { events }\end{array}$ & 35 & 9 & 0.3 & 3 & $4 \%$ & $0 \%$ & $17 \%$ & $14 \%$ \\
\hline $\begin{array}{l}\text { Cross-thematic } \\
\text { information }\end{array}$ & 25 & 11 & 0.4 & 0 & $5 \%$ & $5 \%$ & $17 \%$ & $0 \%$ \\
\hline $\begin{array}{l}\text { Staff stories, } \\
\text { hospital } \\
\text { equipment } \\
\text { and } \\
\text { facilities }\end{array}$ & 19 & 24 & 1.3 & 9 & $10 \%$ & $8 \%$ & $33 \%$ & $29 \%$ \\
\hline $\begin{array}{l}\text { Illness } \\
\text { prevention }\end{array}$ & 19 & 9 & 0.5 & 3 & $4 \%$ & $8 \%$ & $0 \%$ & $14 \%$ \\
\hline $\begin{array}{l}\text { Illness } \\
\quad \text { explanation }\end{array}$ & 19 & 4 & 0.2 & 0 & $1 \%$ & $0 \%$ & $17 \%$ & $0 \%$ \\
\hline Patient stories & 18 & 38 & 2.1 & 6 & $18 \%$ & $20 \%$ & $0 \%$ & $29 \%$ \\
\hline Report on events & 16 & 8 & 0.5 & 2 & $4 \%$ & $3 \%$ & $17 \%$ & $10 \%$ \\
\hline $\begin{array}{l}\text { Hospital in } \\
\text { general }\end{array}$ & 16 & 16 & 1.0 & 8 & $6 \%$ & $5 \%$ & $33 \%$ & $29 \%$ \\
\hline Hospital merger & 10 & 8 & 0.8 & 3 & $1 \%$ & $13 \%$ & $17 \%$ & $14 \%$ \\
\hline $\begin{array}{l}\text { Religious } \\
\text { congregation/ } \\
\text { spirituality }\end{array}$ & 10 & 6 & 0.6 & 1 & $3 \%$ & $3 \%$ & $0 \%$ & $5 \%$ \\
\hline $\begin{array}{l}\text { Qualification of } \\
\text { internal staff/ } \\
\text { external } \\
\text { practitioners }\end{array}$ & 5 & 2 & 0.4 & 0 & $1 \%$ & $0 \%$ & $0 \%$ & $0 \%$ \\
\hline $\begin{array}{l}\text { Career and job } \\
\text { offers }\end{array}$ & 4 & 40 & 10.0 & 2 & $21 \%$ & $10 \%$ & $17 \%$ & $5 \%$ \\
\hline $\begin{array}{l}\text { Prize } \\
\text { competitions/ } \\
\text { raffle }\end{array}$ & 4 & 15 & 3.8 & 5 & $6 \%$ & $5 \%$ & $0 \%$ & $14 \%$ \\
\hline $\begin{array}{l}\text { Explaining } \\
\text { function } \\
\text { of organs }\end{array}$ & 3 & 2 & 0.7 & 2 & $1 \%$ & $0 \%$ & $17 \%$ & $10 \%$ \\
\hline Surveys & 2 & 1 & 0.5 & 0 & $1 \%$ & $0 \%$ & $0 \%$ & $0 \%$ \\
\hline $\begin{array}{l}\text { Other } \\
\text { information }\end{array}$ & 11 & 5 & 0.5 & 2 & $2 \%$ & $3 \%$ & $0 \%$ & $10 \%$ \\
\hline
\end{tabular}

a including reactions of women, men, organizations

users are displayed enlarged. Similar to the emoji-reactions, the broad majority of users only comment on one category of information. In contrast, most IWB-users comment on a variety of topics. Still, there also exist some types of information such as the qualifications of internal staff/ external practitioners or cross-thematic information that were not commented on by IWB-users at all. 


\subsubsection{Shares of different types of information}

The 184 women, men and organizations shared the postings of the hospital 313 times. The three most frequently shared information categories are hospital services/ treatments, career/ job offers as well as dealing with a specific health condition. The highest shares/ posting ratio is achieved by postings concerning career/ job offers, hospital services/ treatments and the hospital merger. IWB-users are accountable for nearly $40 \%$ of the 313 shares. The percentage of users that shared the different types of information mostly differs between the group of women, men, organizations and IWB-users. Moreover, the percentage of users in the IWB-group that shared the single types of

Table 3 Shares of different types of information

\begin{tabular}{|c|c|c|c|c|c|c|c|c|}
\hline \multirow[t]{2}{*}{ Types of information } & \multirow{2}{*}{$\begin{array}{l}\text { Amount of } \\
\text { postings } \\
(\mathrm{N})\end{array}$} & \multicolumn{3}{|l|}{ Shares } & \multicolumn{4}{|l|}{ Users } \\
\hline & & $\begin{array}{l}\text { Total } \\
\text { amount } \\
\text { of } \\
\text { shares }^{\mathrm{a}}\end{array}$ & $\begin{array}{l}\varnothing \text { per } \\
\text { post }^{\mathrm{a}}\end{array}$ & $\begin{array}{l}\text { Amount } \\
\text { of IWB } \\
\text { shares }\end{array}$ & $\begin{array}{l}\% \text { of } \\
\text { women } \\
(N=129)\end{array}$ & $\begin{array}{l}\% \text { of } \\
\text { men } \\
(N=32)\end{array}$ & $\begin{array}{l}\% \text { of } \\
\text { org. } \\
(N=23)\end{array}$ & $\begin{array}{l}\% \text { of } \\
\text { IWB- } \\
\text { user } \\
(N=19)\end{array}$ \\
\hline $\begin{array}{l}\text { Hospital services/ treat- } \\
\text { ments }\end{array}$ & 61 & 91 & 1.5 & 34 & $31 \%$ & $41 \%$ & $35 \%$ & $79 \%$ \\
\hline $\begin{array}{l}\text { Dealing with a health } \\
\text { condition }\end{array}$ & 36 & 25 & 0.7 & 16 & $4 \%$ & $16 \%$ & $22 \%$ & $32 \%$ \\
\hline Invitation to events & 35 & 1 & 0.0 & 0 & $1 \%$ & $0 \%$ & $0 \%$ & $0 \%$ \\
\hline $\begin{array}{l}\text { Cross-thematic } \\
\text { information }\end{array}$ & 25 & 21 & 0.8 & 8 & $9 \%$ & $6 \%$ & $26 \%$ & $37 \%$ \\
\hline $\begin{array}{l}\text { Staff stories, hospital } \\
\text { equipment and } \\
\text { facilities }\end{array}$ & 19 & 11 & 0.6 & 8 & $4 \%$ & $53 \%$ & $4 \%$ & $32 \%$ \\
\hline Illness prevention & 19 & 14 & 0.7 & 5 & $5 \%$ & $3 \%$ & $17 \%$ & $16 \%$ \\
\hline Illness prevention & 19 & 13 & 0.7 & 3 & $5 \%$ & $6 \%$ & $13 \%$ & $11 \%$ \\
\hline Patient stories & 18 & 24 & 1.3 & 13 & $9 \%$ & $13 \%$ & $17 \%$ & $53 \%$ \\
\hline Report on events & 16 & 19 & 1.2 & 12 & $5 \%$ & $9 \%$ & $13 \%$ & $32 \%$ \\
\hline Hospital in general & 16 & 6 & 0.4 & 2 & $4 \%$ & $3 \%$ & $0 \%$ & $11 \%$ \\
\hline Hospital merger & 10 & 15 & 1.5 & 11 & $4 \%$ & $9 \%$ & $9 \%$ & $32 \%$ \\
\hline $\begin{array}{l}\text { Religious congregation/ } \\
\text { spirituality }\end{array}$ & 10 & 4 & 0.4 & 3 & $3 \%$ & $0 \%$ & $0 \%$ & $16 \%$ \\
\hline $\begin{array}{l}\text { Qualification of internal } \\
\text { staff/ external practi- } \\
\text { tioners }\end{array}$ & 5 & 1 & 0.2 & 0 & $1 \%$ & $0 \%$ & $0 \%$ & $0 \%$ \\
\hline Career and job offers & 4 & 59 & 14.8 & 0 & $37 \%$ & $19 \%$ & $0 \%$ & $0 \%$ \\
\hline $\begin{array}{l}\text { Prize competitions/ raf- } \\
\quad \text { fles }\end{array}$ & 4 & 0 & 0.0 & 0 & $0 \%$ & $0 \%$ & $0 \%$ & $0 \%$ \\
\hline $\begin{array}{l}\text { Explaining function of } \\
\text { organs }\end{array}$ & 3 & 1 & 0.3 & 0 & $0 \%$ & $3 \%$ & $0 \%$ & $0 \%$ \\
\hline Surveys & 2 & 1 & 0.5 & 1 & $1 \%$ & $0 \%$ & $0 \%$ & $5 \%$ \\
\hline Other information & 11 & 7 & 0.6 & 5 & $4 \%$ & $3 \%$ & $0 \%$ & $21 \%$ \\
\hline
\end{tabular}

a including reaction of women, men, organization 
information is in nearly one third of the cases lower than the percentage in one of the other groups. Still, more than $30 \%$ of the IWB-users shared postings regarding hospital services/ treatments, patient stories, report on events, hospital merger, staff stories/ hospital equipment/ facilities, the dealing with a specific health condition as well as other additional cross-thematic information. Similar to the comments, this might be a strong indicator that IWB-users share several types of information with their Facebook network. Nevertheless, there also seem to be certain types of information, which are shared by only few IWB-users or not shared at all. Table 3 presents these empirical findings in more detail.

Figure 8 visualizes the relationship between the Facebook users' 313 shares and the different information categories. Consistent with Figs. 6 and 7, the single topics are displayed as triangles and the 19 IWB-users are shown enlarged. Similar to the emojireactions and comments, the broad majority of users shared postings only on one category of information. Most IWB-users instead shared postings in two or more information categories. However, there exist some types of information such as career/ job offers, explaining function of organs, prize competitions/ raffles or invitations to events that are not shared by IWB-users at all.

\section{Discussion}

\section{1 eWOM-engagement at the hospital's Facebook page}

With respect to research question 1, the analyzed types of eWOM include the emojireactions (likes, love, wow, haha, sad, angry) to, comments on or the shares of a posting. Emoji-reactions require less commitment and cognitive efforts than shares or comments (Kim and Yang 2017) and, therefore, seem to be the preferred type of eWOM-behavior on Facebook (Bonsón et al. 2015). This assumption is supported by the present case study, as emoji-reactions account for around $90 \%$ of the analyzed eWOM-communication (12,631 emoji-reactions, 273 comments and 1304 shares). A 'like' is the most common way to react with emoji $(97 \%, \mathrm{n}=12,631)$. As stated before, 'liking' a specific post should not always be interpreted as an approval or feedback towards a post. The individual user might only express the sympathy with the hospital in general.

\subsection{Differences in the eWOM-behavior between Facebook users}

Regarding research question 2 , we can conclude that there are differences in the eWOM behavior between Facebook users. Various authors emphasize differences between males and females regarding motives (Horzum 2016; Sheldon 2008) and intensity (Przepiorka et al. 2016; Shepherd 2016) of Facebook use. This study seems to confirm the existence of such gender-based differences, as 2695 women, compared to only 589 men, engaged in eWOM-communication about the case hospital. The women are responsible for $76 \%$ of the 12,631 emoji-reactions and $71 \%$ of the 273 comments. In addition, women shared a Facebook post nearly four times more often than men. In this way, women seem to be the main source of eWOM about the case hospital's Facebook posts. These gender-specific differences might partly be explained by Levinson et al. 
= Types of Information $\quad \forall$ Female $\quad \Delta=$ Male $\quad$ = Organization

Fig. 6 Relationship between the Facebook users' emoji-reactions and the types of information provided (Harel-Koren Fast Multiscale algorithm graph) 


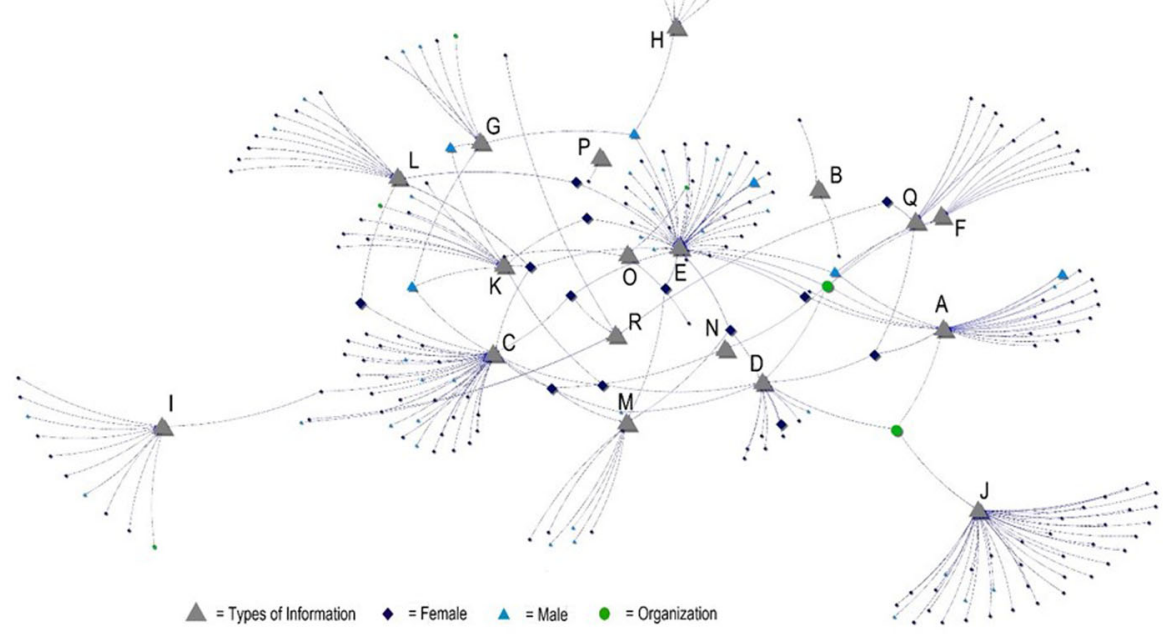

\begin{tabular}{|c|c|c|}
\hline \multicolumn{3}{|c|}{ of Information } \\
\hline $\begin{array}{l}\text { A - Staff stories, hospital equipment and } \\
\text { facilities }\end{array}$ & G - Hospital merger & M - Illness prevention \\
\hline $\begin{array}{l}\text { B - Qualification of internal staff/ external } \\
\text { practitioners }\end{array}$ & H - Religious congregation/ spirituality & $\mathrm{N}$ - Explaining function of organs \\
\hline C - Patient stories & I- Cross-thematic information & O - Illness explanation \\
\hline D - Hospital in general & $\mathrm{J}$ - Career and job offers & P-Surveys \\
\hline E - Hospital services/treatments & $\mathrm{K}$ - Dealing with a health condition & Q - Invitation to events \\
\hline F-Report on events & L - Prize competitions/ raffles & $\mathrm{R}$ - Other information \\
\hline
\end{tabular}

Fig. 7 Relationship between the Facebook users' comments and the types of information provided (HarelKoren Fast Multiscale algorithm graph)

(2005), who point out that women often act as the health advisor for their family. Therefore, women could have an increased interest in engaging in communication about health-related topics, which might include eWOM on a hospital's Facebook site. By separately analyzing the female and male users, the percentage in the women's group which reacts with emojis to a specific type of information, is always similar to the percentage in the men's group. Therefore, even though more women than men react, the preference regarding the information content to which they react seems to be similar. These explorative findings seem to contradict Brandtzaeg (2017), who states that female and male Facebook users have different topics of interest. Nevertheless, the percentage of users that comment or share the different types of information mostly differs between both gender groups. For example, whereas a higher percentage of men comment on postings regarding the hospital services and treatments, a higher proportion of women comment on information about career as well as job offers. Similarly, a higher percentage of women share information about career as well as job offers while a higher proportion of men share staff stories or postings about the hospital's equipment and facilities. However, all comments and shares in the category "career and job offers" concern only one vacancy posting about a two-month holiday internship at the hospital's reception desk. Therefore, this case study may only indicate but not generalize gender-based differences regarding comments on and shares of career or job postings. It remains to be discussed further if the stated differences are subject to a bias that is 
caused by only one posting. Especially, it seems to be interesting to question if the eWOM-behavior of women and men correlates with different types of job vacancies.

By separately analyzing the emoji-reactions, comments and shares, each time $10 \%$ of the users are responsible for an essential part of the eWOM. We call this small proportion, users with "Intensive WOM-Behavior" (IWB). More than $90 \%$ of the IWBusers only engage in one type of eWOM-behavior (emoji-reactions, comments or shares). Whereas IWB-users apply the preferred eWOM-type on a broad variety of different topics, most of the other users only react with emoji to, comment on or share one type of information. Consequently, the eWOM-behavior of the broad majority of the users seems to depend on the variety of information topics provided on the hospital's Facebook page.

\subsection{Differences in the eWOM-behavior towards different types of information}

With respect to research question 3, the literature states that eWOM is affected by the message content (Choi et al. 2017) For example, the number of 'likes' can be positively influenced by the emotional content of the postings (Swani et al. 2013; Liu et al. 2017). In this study, patient stories achieve one of the highest average number of emojireactions (predominantly 'likes') per post, which seems to be in accordance with research to date. Moreover, patient stories generate one of the highest average number

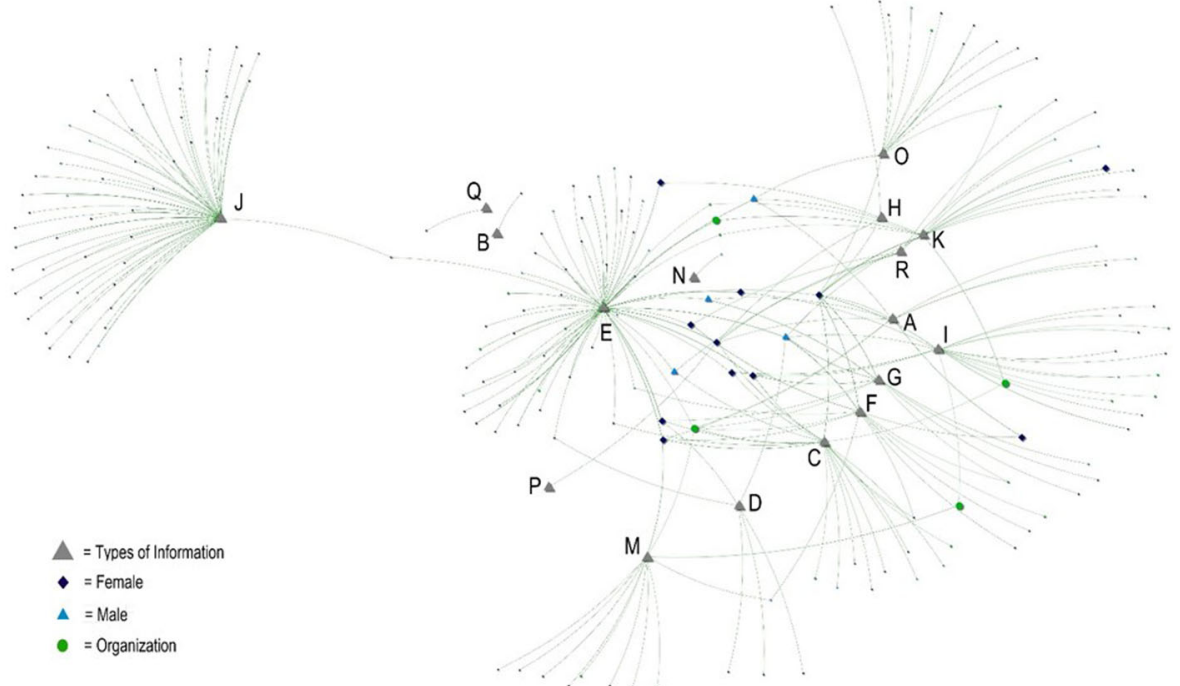

\begin{tabular}{|c|c|c|}
\hline \multicolumn{3}{|c|}{ Types of Information } \\
\hline $\begin{array}{l}\text { A - Staff stories, hospital equipment and } \\
\text { facilities }\end{array}$ & G - Hospital merger & M - Illness prevention \\
\hline $\begin{array}{l}\text { B - Qualification of internal staff/ external } \\
\text { practitioners }\end{array}$ & H - Religious congregation/ spirituality & $\mathrm{N}$ - Explaining function of organs \\
\hline $\begin{array}{l}\text { C - Patient stories } \\
\text { D - Hospital in general } \\
\text { E - Hospital services/ treatments } \\
\text { F - Report on events }\end{array}$ & $\begin{array}{l}\text { I- Cross-thematic information } \\
\mathrm{J} \text { - Career and job offers } \\
\mathrm{K} \text { - Dealing with a health condition } \\
\text { L- Prize competitions/ raffles (not } \\
\text { shared) }\end{array}$ & $\begin{array}{l}\text { O- Illness prevention } \\
\text { P - Surveys } \\
\text { Q - Invitation to events } \\
\text { R - Other information }\end{array}$ \\
\hline
\end{tabular}

Fig. 8 Relationship between the Facebook users' shares and the types of information provided (Harel-Koren Fast Multiscale algorithm graph) 
of comments and shares per post. In addition, the stated broad variety of different topics on the hospital's Facebook page also positively influences the eWOM-behavior. In this way, by providing broad variety of information as well as emphasizing specific topics, managers seem to be able to actively influence the eWOM behavior on the hospital's Facebook account. The eWOM is passed through strong as well as weak ties (e.g. Choi et al. 2017; Goldenberg et al. 2007; Johnson-Brown and Reingen 1987). It strongly circulates within the single network clusters which are mainly formed by strong ties (Hansen 1999; Dubini and Aldrich 1991; Paniculangara and Pacheco 2008). In order to stimulate the spread of eWOM for the hospital, it seems to be important to connect with users of various clusters and stimulate these users to react with emojis, comments or shares. As stated before, in this case study, an essential part of the eWOM is conducted by a small proportion of IWB-users. In this way, a substantial share of eWOM always reaches the same clusters and circulates within them. A shift of the eWOM-behavior from the $10 \%$ of IWB-users towards the $90 \%$ of less active users could enable the hospital to reach more clusters and therefore potentially would have a positive effect on the spread of eWOM. It could be argued that the current distribution of a high amount of eWOM information in only a few clusters might even have negative effects. For example, one IWB-user reacted 243 times towards the 313 released posts. Contacts in the user's cluster might be overwhelmed or even become annoyed by such a high amount of hospital information they receive almost on daily basis. Managers of the hospital have to be aware of this fact and should try to foster a distribution of the information to more network clusters. As stated before, the findings of this study indicate that such a spread of eWOM through the different clusters may be positively influenced by the variety of information posted by the hospital.

\subsection{Limitations and further research}

By answering the research questions, the study at hand offers first exploratory insights into the eWOM-behavior on a hospital's Facebook page. Still, the exploratory research is subject to some limitations, which need to be taken into account in future research. In this way, our study suggests some key directions for further research. For instance, beside gender, no demographic attributes of the Facebook-users were collected. Therefore, there could also be a potential impact of demographic variables, such as age or education towards the stated eWOM-behavior. The study also focuses on the eWOMcommunication on the Facebook page of only one Upper Austrian hospital. Thus, the described findings might be significantly biased by the chosen study design. Further research should investigate the transferability of these findings to the Facebook sites of other hospitals. Richter et al. (2014) state that urban, nonprofit and larger hospitals are more likely to use social media. In follow-up studies, scholars should therefore focus on the potential impact of the hospital's geographical location, profit-status and size towards the eWOM on Facebook. Additionally, this study emphasizes that patient characteristics, such as gender, influence eWOM-behavior. Levinson et al. (2005) point out that women are more likely to prefer an active involvement in medical decision making than men. For this reason, future research could focus on the extent to which women use eWOM in Facebook as a source of information for their medical decisions. Results of such research might help to explain the different eWOM-behavior between women and men on the Facebook page of the hospital in question. Moreover, the 
methodology of this study does not allow a subdivision of the Facebook users into single groups of stakeholders, such as, for example, patients, relatives or employees. Still, Drevs and Hinz (2014) state existing differences between the recommendations of patients and their relatives. Therefore, future studies should analyze the virtual WOM of the different groups of stakeholders separately. A link to an online survey on the hospital's Facebook page could, for instance, allow an examination of the stakeholder motives for seeking, passing and giving health-related recommendations. The COBRA typology by Muntinga et al. (2011) as well as existing studies by Mathwick (2002) or Shao (2009) might provide a framework for such differentiated segmentation of the user-motives and behavior.

\section{Conclusion}

Current literature emphasizes the influence of (electronic) WOM towards the health related behavior of individuals. Nevertheless, only few studies explicitly focus on eWOM in the context of the healthcare sector. This article contributes to existing research by offering first explorative insights into the eWOM-behavior at the Facebook page of an Austrian hospital. The data was collected and analyzed with NodeXL. The software allows us to examine the eWOM behavior of individual Facebook users in the timeframe of 11 month.

The study contributes to the existing literature by confirming emoji-reactions as preferred type of eWOM-behavior on Facebook. In compliance with previous research, we also witness gender-based differences in the eWOM-communication at the hospitals' Facebook site. For most users a broad variety of topics on the Facebook page stimulate the electronic recommendations. Hospital managers have to be aware of the differing demand for information and need to provide appropriate information to their variety of stakeholder groups. One major finding of the study is that only a few individuals are responsible for a substantial part of the eWOM. We describe the communication of these users as Intensive WOM Behavior (IWB). These users apply the preferred eWOM-type on a broad variety of different topics. By providing first insights into the existence of these IWB-users as well as their eWOM-behavior, this study offers new insights to the eWOM in Facebook.

By assessing the eWOM-communication on the hospital's Facebook site, scholars as well as practitioners need to be aware about potential distortions, such strong engagement of IWB-users might cause. Nevertheless, the concept of Intensive WOM Behavior was so far only investigated at the Facebook site of one Austrian hospital. To confirm the proposed concept, further research need to validate the explorative findings to different settings in the health care sector. By doing so, this paper offers a conceptual as well as a methodological approach that can be used.

Funding information Open Access funding provided by University of Applied Sciences Upper Austria.

Open Access This article is licensed under a Creative Commons Attribution 4.0 International License, which permits use, sharing, adaptation, distribution and reproduction in any medium or format, as long as you give appropriate credit to the original author(s) and the source, provide a link to the Creative Commons licence, and indicate if changes were made. The images or other third party material in this article are included in the article's Creative Commons licence, unless indicated otherwise in a credit line to the material. If material is not 
included in the article's Creative Commons licence and your intended use is not permitted by statutory regulation or exceeds the permitted use, you will need to obtain permission directly from the copyright holder. To view a copy of this licence, visit http://creativecommons.org/licenses/by/4.0/.

\section{References}

Abedin, T., Al Mamun, M., Lasker, M. A. A., Ahmed, S. W., Shommu, N., Rumana, N., \& Turin, T. C. (2017). Social media as a platform for information about diabetes foot care: a study of Facebook groups. Canadian Journal of Diabetes, 41, 97-10.

Abrantes, J. L., Seabra, C., Lages, C. R., \& Jayawardhena, C. (2013). Drivers of in-group and out-of-group electronic word-of-mouth (EWOM). European Journal of Marketing, 47(7), 1067-1088.

Adzharuddin, N. A., \& Ramly, N. M. (2015). Nourishing healthcare information over Facebook, Procedia -. Social and Behavioral Sciences, 172, 383-389.

Andersen, K. N., Medaglia, R., \& Henriksen, H. Z. (2012). Social media in public health care: impact domain propositions. Government Information Quarterly, 29, 462-469.

Bonsón, E., Royo, S., \& Ratkai, M. (2015). Citizens' engagement on local governments' Facebook sites. An empirical analysis: the impact of different media and content types in Western Europe. Government Information Quarterly, 32, 52-62.

Brandtzaeg, P. B. (2017). Facebook is no 'great equalizer': a big data approach to gender differences in civic engagement across countries. Social Science Computer Review, 35(1), 103-125.

Buchanan, M. (2002). Nexus. Small worlds and the groundbreaking science of networks. New York: W.W. Norton and Company.

Capaldo, A. (2007). Network structure and innovation: the leveraging of a dual network as a distinctive relational capability. Strategic Management Journal, 28, 585-608.

Choi, Y. K., Seo, Y., \& Yoon, S. (2017). E-WOM messaging on social media: social ties, temporal distance, and message concreteness. Internet Research, 27(3), 1-22.

Chu, S.-C., \& Kim, Y. (2011). Determinants of consumer engagement in electronic word-of-mouth (eWOM) in social networking sites. International Journal of Advertising, 30(1), 47-75.

De Vries, L., Gensler, S., \& Leeflang, P. S. H. (2012). Popularity of brand posts on brand fan pages: an investigation of the effects of social media marketing. Journal of Interactive Marketing, 26(2), 83-91.

Dellarocas, C. (2003). The digitization of word of mouth: promise and challenges of online feedback mechanisms. Management Science, 49(10), 1407-1424.

Drevs, F., \& Hinz, V. (2014). Who chooses, who uses, who rates: the impact of agency on electronic word-ofmouth about hospitals stays. Health Care Management Review, 39(3), 223-233.

Dubini, P., \& Aldrich, H. (1991). Personal and extended networks are central to the entrepreneurial process. Journal of Business Venturing, 6, 305-313.

Duran, C., Filiz, A., Cetindere, A., \& Tiryaki, S. (2016). Word of mouth marketing: an empirical investigation in healthcare services. Journal of Management Marketing and Logistics, 3(3), 232-240.

Edwards, S. (2006). Special issue on electronic word-of-mouth and its relationship with advertising, marketing and communication. Journal of Interactive Advertising, 6, 1-2.

Ferguson, R. (2008). Word of mouth and viral marketing: taking the temperature of the hottest trends in marketing. Journal of Consumer Marketing, 25(3), 179-182.

Fu, P.-W., Wu, C.-C., \& Cho, Y.-J. (2017). What makes users share content on facebook? Compatibility among psychological incentive, social capital focus, and content type. Computers in Human Behavior, $67,23-32$.

Gheorghe, L. R., \& Liao, M.-N. (2012). Investigating Romanian healthcare consumer behaviour in online communities: qualitative research on negative eWOM. Procedia - Social and Behavioral Sciences, 62(24), 268-274.

Glover, M., Khalilzadeh, O., Choy, G., Prabhaka, A. M., Pandharipande, P. V., \& Gazelle, S. G. (2015). Hospital evaluations by social media: a comparative analysis of Facebook ratings among performance outliers. Journal of General Internal Medicine, 30(10), 1440-1446.

Goldenberg, J., Libai, B., Moldovan, S., \& Muller, E. (2007). The NPV of bad news. International Journal of Research in Marketing, 24, 186-200. 
Gomes, R. F., \& Casais, B. (2018). Feelings generated by threat appeals in social marketing: text and emoji analysis of user reactions to anorexia nervosa campaigns in social media. International Review on Public and Nonprofit Marketing., 15(4), 591-607.

Granovetter, M. (1973). The strength of weak ties. American Journal of Sociology, 78, 1360-1380.

Granovetter, M. (1983). The strength of weak ties: a network theory revisited. Sociological Theory, 1, 201233.

Greene, J. A., Choudhry, N. K., Kilabuk, E., \& Shrank, W. H. (2011). Online social networking by patients with diabetes: a qualitative evaluation of communication with Facebook. Journal of General Internal Medicine, 26(3), 287-292.

Griffis, H. M., Kilaru, A. S., Werner, R. M., Asch, D. A., Hershey, J. C., Hill, S., Ha, Y. P., Sellers, A., Mahoney, K., Wong, C., \& Merchant, R. M. (2014). Use of social media across US hospitals: descriptive analysis of adoption and utilization. Journal of Medical Internet Research, 16(11), e264.

Hansen, M. T. (1999). The search-transfer problem: the role of weak ties in sharing knowledge cross organization subunits. Administrative Science Quarterly, 44, 82-111.

Hansen, D. L., Shneiderman, B., \& Smith, M. A. (2011). Analyzing social media networks with nodexl insights from a connected world. Morgan Kauffman: Burlington.

Hawn, C. (2009). Take two aspirin and tweet me in the morning: how twitter, Facebook, and other social media are reshaping health care. Health Affairs, 28(2), 361-368.

Hennig-Thurau, T., Gwinner, K. P., Walsh, G., \& Gremler, D. D. (2004). Electronic word-of-mouth via consumer-opinion platforms: what motivates consumers to articulate themselves on the internet? Journal of Interactive Marketing, 18(1), 38-52.

Horzum, M. B. (2016). Examining the relationship to gender and personality on the purpose of Facebook usage of Turkish university students. Computers in Human Behavior, 64, 319-328.

Huppertz, J. W., \& Otto, P. (2018). Predicting HCAHPS scores from hospitals' social media pages: a sentiment analysis. Health Care Management Review, 43(4), 359-367.

Jenssen, J. I., \& Koenig, H. F. (2002). The effect of social networks on resource access and business startups. European Planning Studies, 10, 1039-1046.

Johnson-Brown, J., \& Reingen, P. H. (1987). Social ties and word-of-mouth referral behavior. Journal of Consumer Research, 14, 350-362.

Joiner, R., Cuprinskaite, J., Dapkeviciute, L., Johnson, H., Gavin, J., \& Brosnan, M. (2016). Gender differences in response to Facebook status updates from same and opposite gender friends. Computers in Human Behavior, 58, 407-412.

Khalid, S., Ahmed, M. A., \& Ahmad, Z. (2013). Word-of-mouth communications: \$ powerful contributor to consumers decision-making in healthcare market. International Journal of Business and Management Invention, 2(5), 50-59.

Kim, C., \& Yang, S.-U. (2017). Like, comment, and share on Facebook: how each behavior differs from the other. Public Relations Review, 43, 441-449.

Korda, H., \& Itani, Z. (2013). Harnessing social media for health promotion and behavior change. Health Promotion Practice, 14(1), 15-23.

Koroleva, K., \& Kane, G. C. (2017). Relational affordances of information processing on Facebook. Information \& Management, 54, 560-572.

Kucukemiroglu, S., \& Kara, A. (2015). Online word-of-mouth communication on social networking sites: an empirical study of Facebook users. International Journal of Commerce and Management, 25(1), 2-20.

Levinson, W., Kao, A., Kuby, A., \& Thisted, R. A. (2005). Not all patients want to participate in decision making. Journal of General Internal Medicine, 20(6), 531-535.

Lis, B., \& Korchmar, S. (2013). Digitales Empfehlungsmarketing - Konzeption, Theorien und Determinanten zur Glaubwürdigkeit des Electronic Word-of-Mouth (EWOM), Wiebaden.

Liu, J., Li, C., Ji, Y. G., North, M., \& Yang, F. (2017). Like it or not: the fortune 500's Facebook strategies to generate users' electronic word-of-mouth. Computers in Human Behavior, 73(August), 605-613.

Luarn, P., Kuo, H.-C., Chiu, Y.-P., \& Chang, S.-C. (2015). Social support on Facebook: the influence of tie strength and gender differences. International Journal of Electronic Commerce Studies, 6(1), 37-50.

Mathwick, C. (2002). Understanding the online consumer: a typology of online relational norms and behavior. Journal of Interactive Marketing, 16(1), 40-55.

McCaughey, D., Baumgardner, C., Gaudes, A., LaRochelle, D., Wu, K. J., \& Raichura, T. (2014). Best practices in social media: utilizing a value matrix to assess social media's impact on health care. Social Science Computer Review, 32(5), 575-589.

Muntinga, D. G., Moorman, M., \& Smit, E. G. (2011). Introducing COBRAs, exploring motivations for brand-related social media use. International Journal of Advertising, 30(1), 13-46. 
Oleszkiewicz, A., Karwowski, M., Pisanski, K., Sorokowski, P., Sobrado, B., \& Sorokowska, A. (2017). Who uses emoticons? Data from 86702 Facebook users. Personality and Individual Differences, 119, 289295.

Paniculangara, J., \& Pacheco, B. (2008). Effects of tie strength and tie valence on consumer word-of-mouth communication and altruistic intentions. Advances in Consumer Research, 8, 324-325.

Przepiorka, A., Błachnio, A., \& Díaz-Morales, J. F. (2016). Problematic Facebook use and procrastination. Computers in Human Behavior, 65, 59-64.

Richter, J. P., Muhlestein, D. B., \& Wilks, C. E. A. (2014). Social media: how hospitals use it, and opportunities for future use. Journal of Healthcare Management, 59(6), 447-461.

Shao, G. (2009). Understanding the appeal of user-generated media: a uses and gratifications perspective. Internet Research, 19(1), 7-25.

Sheldon, P. (2008). Student favorite: Facebook and motives for its use. Southwestern Mass Communication Journal, 23(2), 39-53.

Shepherd, R. P. (2016). Men, women, and web 2.0 writing: gender difference in Facebook composing. Computers and Composition, 39, 14-26.

Smailhodzic, E., Hooijsma, W., Boonstra, A., \& Langley, D. J. (2016). Social media use in healthcare: a systematic review of effects on patients and on their relationship with healthcare professionals. $B M C$ Health Services Research, 16(442), 1-14.

Smith, T., Coyle, J. R., Lightfoot, E., \& Scott, A. (2007). Reconsidering models of influence: the relationship between consumer social networks and word-of-mouth effectiveness. Journal of Advertising Research, 47(4), 387-397.

Swani, K., Milne, G., \& Brown, B. P. (2013). Spreading the word through likes on Facebook. Evaluating the message strategy effectiveness of fortune 500 companies. Journal of Research in Interactive Marketing, 7(4), 269-294.

Tursunbayeva, A., Franco, M., \& Pagliari, C. (2017). Use of social media for e-government in the public health sector: a systematic review of published studies. Government Information Quarterly, 34, 270-282.

Verhoef, L. M., Van de Belt, T. H., Engelen, L., Schoonhoven, L., \& Kool, R. B. (2014). Social media and rating sites as tools to understanding quality of care: a scoping review. Journal of Medical Internet Research, 16(2), e56.

Publisher's note Springer Nature remains neutral with regard to jurisdictional claims in published maps and institutional affiliations. 